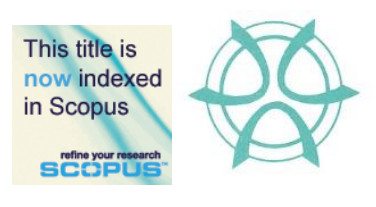

PLANNING MALAYSIA:

Journal of the Malaysian Institute of Planners

VOLUME 16 ISSUE 2 (2018), Page 304 - 322

\title{
CLASSIFICATIONS OF CLASSICAL MALAY ARISTOCRATIC ARCHITECTURE: IDENTIFYING GENERIC AND VARIANT FORMS
}

\author{
Tengku Anis Qarihah Raja Abdul Kadir ${ }^{1}$, Puteri Shireen Jahn Kassim², \\ Noor Hanita Abdul Majid ${ }^{3}$, \& Zumahiran Kamaruddin ${ }^{4}$ \\ ${ }^{1,2,3,4}$ Kulliyyah of Architecture and Environmental Design \\ INTERNATIONAL ISLAMIC UNIVERSITY MALAYSIA
}

\begin{abstract}
The paper reports on a basic classification based on formal and morphological similarities of large vernacular buildings across the Malay region, based on their frontages; with the aim of developing a universal regional language and set of rules of local architecture for urban and multi-storeys typologies. Generally, seen as idiosyncratic and individualistic, Malay regional palaces and mansions across different states and regions under former Sultanates, exhibit different vocabularies, yet have underlying similarities. While form and architecture may arise from the local technology and construction methods of the era, aesthetic expressions of these palaces recall formal archetypes which can be described, and characterised, regardless of location. Focusing on palaces in Malaysia and East Sumatran region from the late 1800s onwards, recurring forms of a MalayClassical language are observed and classified into generic morphologies of frontages. The aim is towards formal taxonomy that can represent a more inclusive architectural identity of the region, rather than identities based on nations. By defining the 'generic' and the 'variant', significant palaces across the Malay region are discussed and positioned within a classification based on a range of generic archetypes. Variants include cases which have absorbed external influences yet retain the essences of local form, while some examples, refer to elements that have modernised been yet represent the last offshoot or branch of the same region. To identify generic rules and frameworks of design, the regional roots of form, including frontages, for public buildings is crucial for urbanscape and the urgency of developing guidelines and a set of compositional rules and language of urban architecture derived from the essences of tradition and past forms.
\end{abstract}

Keywords: classical rules, regionalism, Malay identity, aristocratic form 
PLANNING MALAYSIA

Journal of the Malaysia Institute of Planners (2018)

\section{INTRODUCTION}

The idea of the ' Classical' is generally related to a set of elements which are imported from the West or related to European traditions. Yet Porphyrios (1989) defines 'Classicality' in architecture as not a 'style" but an ageless principle; or a grouping of similarities and common forms. He states: 'On the contrary, what makes Classical architecture possible is the dialogic relationship it establishes between the craft of building and the art of architecture. Our imagination traverses this dialogic space between, a pergola and a colonnade and establishes hierarchies, levels of propriety and communicable systems of evaluation. The classical architecture also needs another dialogic relationship: this time the relationship between one building and another.'

Classicality, as an architectural language, though having Greek origins, began to be promulgated and practised as a 'treatise' or 'set of common principles' for design of public buildings in the time of the Rennaisance. Evers, Biermann, and Thoenes (2003) highlight, '...Bearing this in mind, it is no coincidence that the first three major treatises on the architecture of the early Renaissance period arose at the courts of Italy'. Both Evers et al. (2003) and Rae (2017) recall the origins of Classicality as a principle in the royal realm of the Italian courts, where both the 'nobility' and the 'bourgeois' played a role in defining monumental architecture in the public realm. Malay architectural traditions have their public realm in the 'monumental' expressions of their palaces, yet presently, many have linked the Malay design language to a set of expressions and elements of vernacular form. This must has limited its potential as a public language, as the 'vernacular' has historically evolved into, and linked to the movement of the 'picturesque', while classical architecture is what gave public buildings the rule of 'controlled design' and a 'rationally'-grounded set of rules the govern large, public buildings.

Throughout the Malay-Nusantara regions, palaces have been the center of Sultanate polities, and reflect a range of functions and types, yet essentially the larger or main types play a dual role; a residential and administrative one. These larger, more complex types typically have frontages and in traditional times, are generally open to the public, with open spaces that essentially represent the 'public realm' or what the renowned philosopher Hannah Arendt, calls 'the space of public appearance'. In order to respond to the need for local identity in cities and in public buildings, these traditional roots needed to be studied and mapped. Yet the South-East Asian region represent one of the most culturally diverse region in the world. 'Aristocratic' architecture refers to a range of types and language, and forms, which arise from aristocratic groups or persons, and which have both private and public zones, shared by the community or polity. Due to their symbolic position, these have absorbed neighboring or external influences over centuries. Palaces include those which are conventionally referred to as mansions and house of community leaders. These reflect some of 
Tengku Anis Qarihah Raja Abdul Kadir, Puteri Shireen J.K, Noor Hanita A.M, \& Zumahiran K.

Classifications of Classical Malay Aristocratic Architecture: Identifying Generic and Variant Forms

the highest forms of artisanal skills of the locale and a confluence of aesthetic identity in the region. Example of aristocratic architecture which are not royal palaces are, the Panglima Ghani House, Melaka and Dato Bji Sura House, Kota Duyong, Terenggany which reflect Malay form and identity; yet demonstrate the hybridity of cultures as they demonstrate syncretic or multicultural elements.

\section{THE "VERNACULAR" AND THE "CLASSICAL"}

While vernacular houses refer to what is known as 'architecture without architects' and generally encompass the multitude of residential buildings which reflect the age-old traditions of local artisanship, the localities prevailing materials, and enduring character of place, the 'Classical' is often linked' to the 'symbolic', or the 'representational' or simply, 'self-conscious' buildings. Palaces have frontages which are designed 'conscious' of its role in the public realm and hence are conceptualised as a whole; and often reflect a degree of classicality. 'Classicality', as a set of norms and key rules of an aesthetic style, has thus often been linked to frontages that express symmetry, ceremoniality and infuse with a degree of symbolism. Hence in the ancient past, these are buildings which were designed with a distinctive 'facade'. Classicality is related to what is 'enduring' and 'timeless' (Summerson, 1980). He states: 'A classical building is one whose decorative elements are derived directly or indirectly from the architectural vocabulary of the ancient world'. A 'classical language' is a 'composition of elements', which 'together... shows the relationship of all parts.... the classical architect sought for symmetry and harmony. Symmetry and balance can be summarised as the principle of composing a series of combined elements in a simple yet visual approach, and these are reflected the 'public' face of Malay vernacular palaces; which are an outcome of the higher resources, capabilities and wealth of the Malay courts.

South East Asia in the 1800s, was a region suddenly infused with dynamic economic energies (Gullick, 1987). The 'public' buildings of these region, whether they are from the ruling elites or community leaders, became infused with new technology and often renovated with additional and stylised masonry elements. There was a degree of modernisation, which was the result of a natural evolution of progress, and the need to appear 'modern', and these stylisations were not necessarily 'Colonial' design or the result of conscious copying of imported styles. Across the region, palaces became the site of a dynamic tension, between the identity of the Sultanate-based polity and the pressure of external powers to the region. Yet until early 1900s, these had consistently reflect local culture, rather than imported styles. It is important that shared characteristics are identified, and in this study, is defined as what is 'Generic' including any characteristic underlying overall form of, or relating to a class or group of things or objects. Hence the term 'generic' can be used to organise a taxonomy, which is crucial in order to create new terminologies, or an 
PLANNING MALAYSIA

Journal of the Malaysia Institute of Planners (2018)

organised database for information retrieval. 'Variants' is generally known as forms manifesting variety, deviation or disagreement, which deviate slightly from the standard form, can then refer to the specific variation between the subregion or subcultures. Hourigan (2015) has observed a continuing difficulty of classifying the vernacular forms, due to its wide and diverse range of expressions. Hence to derive principles, the search for a framework of classification of palaces must begin with the 'generic'. Wong (1995) suggest such generic forms from observing how these palaces are mainly reflections of the Malay vernacular 'archetypical' houses, which evolve and become 'enlarged' to public buildings which are essentially state-based styles (Nasir \& Wan Teh, 1997).

\section{METHODOLOGY}

Based on measured drawings, and a collection of palatial photos, historical documentations including drawings of individual case studies (Mohamad Rasdi, Mohd. Ali, Syed Ariffin, Mursib, \& Mohamad, 2005), the study attempts to define overall form and observed elements and language that can constitute generic forms, while variants are derivations from the consistency of such generic forms and their vocabulary. Abd Rashid and Che Amat (2014) usefully divides the Malay language into 'structure', and 'ornamentation'; while Shuaib (2013) had usefully outlined; in his description of the essentials of the Kelantan style, by dividing into specific elements of overall architecture, construction and ornamentation. Jahn Kassim, Nawawi and Abdul Majid (2017) charted the evolution of architectural works and buildings in South East Asia, to extend the Malay language and identity making in architecture to include recent modern urbanscape and 'critical' attempts to express regionalism in a range of modern typologies. Yet in terms of region, one must differentiate between the boundaries of the 'nation' and the 'region' as ethnicity is often harnessed for a specific national agenda, rather than refer to a historical regional phenomena. The broader geographical boundaries of the Malay world have been discussed by many (Milner, 2011, Andaya, 2010), but to develop the region's aesthetic rules, one must also delve into its origins. Ibrahim (2017) states, '...The (Malay) royal palaces recall a sense of ideal form. Derived from a timber-based construction tradition, the typology was developed through a rich layering of spatial and aesthetic treatments. The range of expression and variations of treatments and proportions are adapted into systems of walls, windows and openings. These palaces demonstrate the Malay grammar which reflects the rich traditions of the Malay world.'

A relook at aristocratic forms including palaces is thus necessary to search and define the shared characteristics of a region. The attempt is to uncover underlying principles and rules in an attempt to link a diverse region and go beyond the idiosyncratic and parochial; and into the 'universal'. The significance of focusing on the Classical is to represent an alternative to the 'vernacular' and 
Tengku Anis Qarihah Raja Abdul Kadir, Puteri Shireen J.K, Noor Hanita A.M, \& Zumahiran K.

Classifications of Classical Malay Aristocratic Architecture: Identifying Generic and Variant Forms

to elevate and allow rules to be defined for modern buildings and thus critically relate past forms to the rising urbanisation of cities. The research also uncovers a shared vocabulary derived from its shared roots, including its origins from timber forms and construction. Watkin (2011) interestingly highlights how Classical architectural rules in the West had begun in the same way, i.e. through the 'transmutation' or the 'petrification' of timber elements, for example, the Greek pediment was initially related to the gable roof of the local timber buildings of its ancient past. The aim is towards a theory which transcends the moment and reveals an architectural idea. The desired result is the development of set of rules that could be used to generate ideas. The aim is delineate archetypal forms to recall patterns towards formative ideas from a diverse resource and language, which further language might evolve. It can be observed that certain patterns persist through time, regardless of the relationship to place.

\section{CASE STUDIES AND FOCUSING ON A REGION}

Milner (2011) and different researchers have defined the Malay world and its geographical boundaries as generally encompassing amongst others, Indonesia, Malaysia, Borneo, South Philiphines, South Cambodia and South Thailand. Though there are slight differences in the definition, what is agreed and commonly found is that the origin of the Malay region can be traced to an area in South Sumatera around the Jambi/Palembang region (Milner, 2011; Andaya, 2010). Andaya (2010) for example, referred to the Malay world lands as the 'Sea of Malayu'. As he usefully observes: 'For the Malayu, who were shaped by their orientation to the sea and to the riverine environment in which they lived, stretches of land were viewed as barriers that fortunately could be breached by short land passages'. Reid (2004) defines the Malay region as Kerajaan Melayu ('Malay kingdoms'), as those lands ruled by Malay Sultanares and refers to various lands and regions encompassing Brunei, Indonesia, Malaysia, Singapore, Southern Thailand, Sumatra, Borneo and is sometimes used interchangeably with the concepts of 'The Malay Archipelago' and 'Nusantara'.

The following case studies include the palaces and aristocratic buildings in East coast of Malaysia, Brunei, Indonesia, Singapore, Southern Thailand and Sumatra. Each case study is studied in terms of frontages and spatial form and through time, distinctive aesthetic additions and stylizations of ornamentations are noted. What is consistently seen is how these building demonstrate a Classicality, yet tinged with a refined use of complex decorative motifs derived from the local flora, and which can be said as the hallmark of the 'high' aristocratic styles. The forms and treatments are the outcome of the resources of the local monarch/aristocrat and the highest groups of artisans, or individual craftsmen. Decorative elements are often expressed at the 'edges' of elements of such palatial forms, i.e. such as adorning the eaves, fascia boards, and doors. These finials, function like decorative 'lace' adorning a dress or clothes of a person. In 
architecture, these decorative motifs draw attention to the upper 'class' aesthetic identity of the building and on closer look, the Malay world is distinctive for the inspired patterns in architecture, extracted from the surrounding flora and fauna, instantly reflecting the closeness between the locality and the artisans.

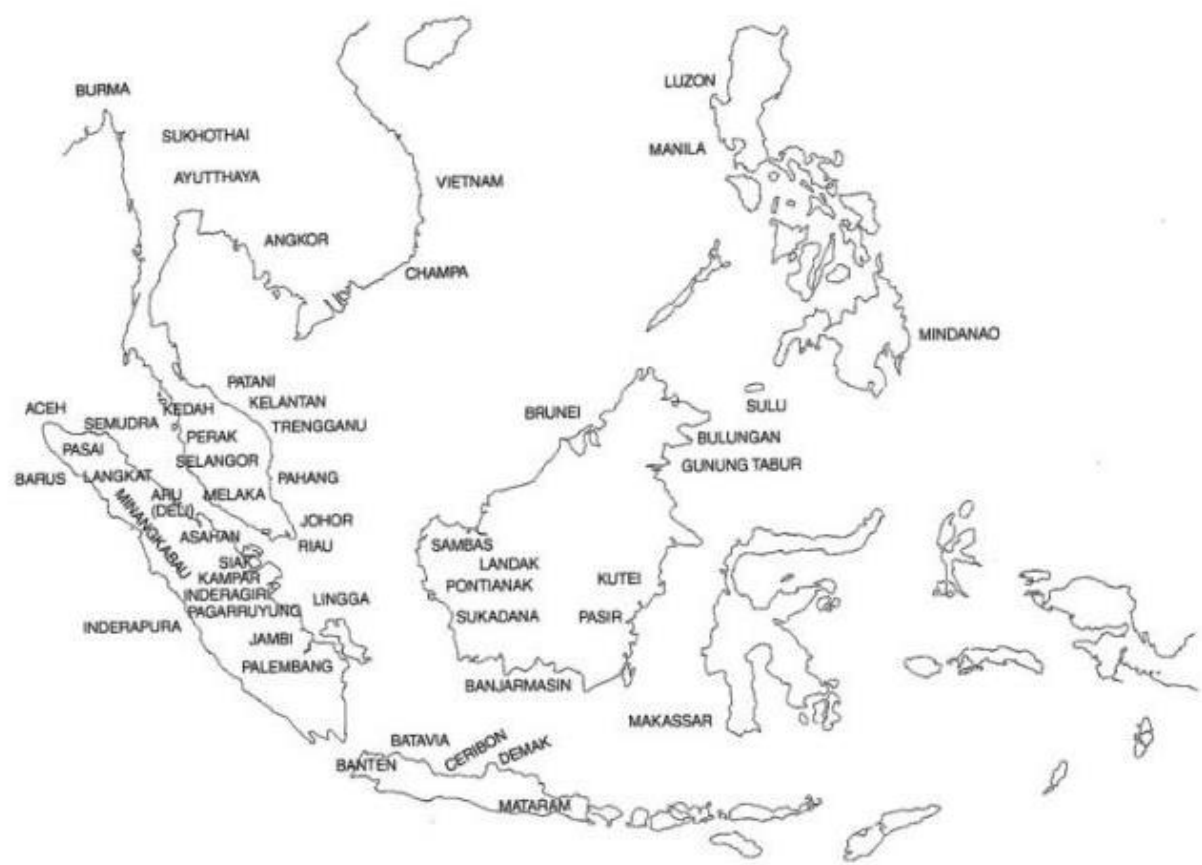

Figure 1: The reaches of the 'Malay region' and the locations of pre-colonial Sultanates

Source: Milner, 2011

Spatially, the palace reflect the 'tropical archetype', and is typically a large house with an enhanced portico, and the typology is generally imbued with a ceremonial character, particularly in the frontages of the structures. Palaces and aristocratic structures were during these times, the 'theatrical' version of the 'vernacular'. Their 'classical' features are often representing the ethos and personality including the ingenuity of the monarch himself who often acts as the designer or concept maker of the building style and expression. While it can be argued that palatial forms often reflected the whims, idiosyncrasies and predispositions of individual monarchs, yet on closer inspection, the study suggests that there are shared characteristics of a 'Classical' Malay identity which have evolved. These forms were later recognized as complexes that reflected the apotheosis of the Malay vernacular. They demonstrate different parts of a continuum of styles from Sultanate to Sultanate, yet there are overlapping patterns due to the hybridization of 'civilizations' across time and place. These 
Tengku Anis Qarihah Raja Abdul Kadir, Puteri Shireen J.K, Noor Hanita A.M, \& Zumahiran K.

Classifications of Classical Malay Aristocratic Architecture: Identifying Generic and Variant Forms

have been linked to dynamically changing 'galactic' polities (Andaya, 2010) and manifest also in a range of expressions of hybrid cultures. Palaces also reflect a form of localized 'Classicality', which reflect the Malay social structure, in space but elevationally, is imbued with local craftsmanship and local motifs. The palace form is a reflection of an essential Malay feudal organization, with similar private and semi-public spatial domains. The complexity of domains varies, and variants can be traced to a root, and the traditional houses reflect a condensed version of the larger palaces, while portraying the same spatial divisions. In palaces, these are amplified in a hierarchical sense. Both horizontal and vertical façade morphologies mirrors the social structure of the feudal Malay world.

The regions of Malaysia and Eastern Sumatera which borders the Straits of Malacca occupy a central position in the regional origin of the 'Melayu' before and after the fall of the Malacca Empire. Historically the Malay states on both sides of the Straits of Malacca lie on opposing sides of a dynamic region bordering and facing an active waterway. These have had active political, economic and cultural exchanges in the past centuries. The Anglo-Dutch Treaty of 1824 had massive repercussions in the region, and which had culturally, and geographically divided what was a homogenous cultural region into two blocks of cultural domains. The Dutch had secured British settlements such as Bengkulu and Sumatera, in exchange for ceding control of their lands in the Malay Peninsula and Dutch India. The common region and universality of the Malay Sumatera culture and civilization was once connected universally and considered as one region and the historical circumstances became a series of nations. Andaya (2010) highlights how the unique geographic region was then separated by an event in history, '...The 1824 agreement represents a turning point in the shaping of modern Malaysia, for the division of the Malay would down the Melaka Straits laid the basis for the contemporary boundary with Indonesia. Setting aside centuries of history without a qualm, the Riau-Johor kingdom was irrevocably divided, and the cultural unity of east coast Sumatra and the Peninsula arbitrarily severed.

During the nineteenth century, palaces reflect the traditional sociopolitical systems of the Malay civilizations and were manifested in forms that reflects spaces underlying the core cultural institutions that played both spiritual and cultural role in the region. Amoroso (2002) further describes, '...Malay politics before colonial rule was control of workforce embedded in a spiritual system of leadership' and 'their success was measured by graceful demeanour and the spiritual rewards they bestowed as much as by their military achievements'. Gullick (1987) similarly observes the central position of the Malay rulers in defining the core of the Malay culture and practices of these rulers was due to, '...the justification for giving so much prominence to them is that they play a leading part in their communities. By their office, they were men of influence, whose precept and example had a widespread effect, especially in the 
PLANNING MALAYSIA

Journal of the Malaysia Institute of Planners (2018)

upper class of Malay society, which came into close contact with them and related their status to ties of kingship with the royal dynasty, or the holding of court office. The rulers were also more exposed than most of their subject to external influences...'

In the case studies mentioned, and during this era, physical alterations were done by the ruling monarchs, but often these were always principle alterations. Changes were made but within the archetypical form and aspects of language of the locality that were sustained. Nasir and Wan Teh (1997) observe, '...The beautiful carvings produced at the palace are associated with the status symbol of an administration and indirectly had accorded recognition to the art of traditional Malay woodcarving'. In the words of Andaya (2010, p:80), 'A simple arrangement prevailed in the Malay areas, with a Malay kingdom consisting of a sultan with many of his residing close to the royal residence, and other family networks headed by powerful officials or chiefs with their constituencies.' Malay subjects considered themselves not in states or governments but in a 'Kerajaan' which can be defined as a system or 'the condition of having a raja'. As Milner (2011) describes, '...The Malay rulers reflected the organizing principle in the Malay world'. As custodians of its culture, the Malay Sultans and the aristocracy is at the core of its society. The rulers were judged or assessed by relating his action on how the institutional system preserved the customs and traditions of the people, and the ruler is at the apex of a system.

\section{BASIS OF METHODOLOGY}

Fletcher (1996) had published on a well-known 'tree of architecture' in which different styles of the Western architecture were classified according to façade style, era or period, technology, structure and building ornamentation. He had chronologically classified them into styles and language including architectural form. In his classification, what governed the classification was the more symbolic buildings of the society or civilisation, such as palaces, churches and forts rather than houses. In the traditional Malay style, there is generally an abundant use of columns, pitched roofs, naturally ventilated porticos, louvres, tall windows, adornment of roof finials, and decorative panels, and thus a common pattern that can be identified and variations can be derived from the 'generic'. These variants reflect local resources and the skills of their societies and are derivative of local socio-political systems. Based on measured drawings and digital information gathered, a series of elevational and spatial-morphological studies were undertaken through observing the character of the façade and associated layouts. Both facades and the spaces directly behind the facades are of interest. The cases are derived a range of multiple centres in Peninsular Malaysia and East Sumatera built from 1600 to 1930, similarities in archetypical forms are observed and grouped according to similarities in character. Regarding the era, the cases were focused from 1800 onwards to 1930, yet one old mosque is traced 
Tengku Anis Qarihah Raja Abdul Kadir, Puteri Shireen J.K, Noor Hanita A.M, \& Zumahiran K.

Classifications of Classical Malay Aristocratic Architecture: Identifying Generic and Variant Forms

as far back as the 1600s. The significance of the 1920s as a cut-off point is as highlighted by Gullick (1987) who provided a key insight into the times, '...The nineteenth century appears to have been the large age of unchanging stability and the twentieth-century mars the beginning of accelerating processes of social change which continue to own to modern times. The end of an epoch and the beginning of another cannot be dated precisely, but one can recognise that say by 1920, age had ended, and another had begun.'

The methodology of deriving generic forms refers to Clark and Pause (2012). They had similarly mapped architectural configurations in terms of themes and intentions and used a research methodology based on design analysis and shape. The methodologies being adapted in this study is similar; the shape of layouts and facades are linked to different types, and are expressed as formative ideas and simple diagrams. These simple diagrams or abstractions are intended to convey the essential characteristics and relationships in order to focus on specific physical attributes which essentially represent the building's architecture, style, type, proportion, scale and facade expression. The diagrams are developed as two and three- dimensional forms including the overall space layout and configurations of the facades. This research is not exhaustive; but will progressively include examples to illustrate both the fundamentals and nuances of the idea and theory. The analysis of palatial configurations, façades and forms derived from the consequence of multiple interpretations, dominant patterns and formative features of these buildings.

\section{RESULTS}

Based on the analysis, the study initially identifies the 'generic' and limited variations of frontages, and had divided these into five essential typologies or archetypes (Figure 2). These archetypes are seen as formal characterisation of its elevations and these archetypes are supported by similar patterns in the observed spatial layout. In all cases, the study initially mapped fully timber palaces which constitute the essential roots of the Malay world. The palaces are then organised according to morphology or shape of roof, body or base. Variations due to the evolution of time are also mapped and the changes in the elevational language from the essential timber to the essentially masonry vocabulary and expressions are mapped. Below are the observed basic typologies, or archetypical forms which can be arguably identified as reflecting several forms. 


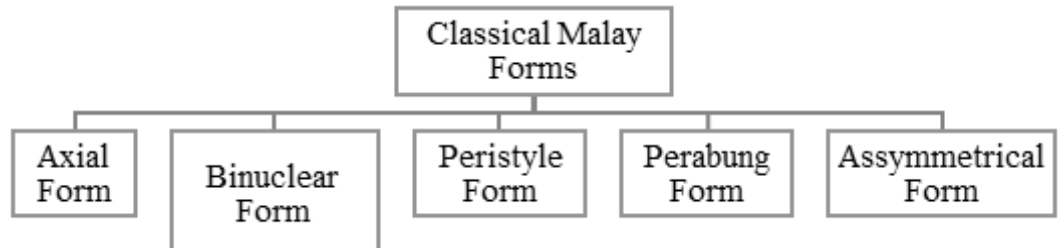

Figure 2: Observed typologies of classical Malay forms

\section{The 'Axial' Form}

This form represents a frontal elevation character which is axial and whose center contains the highest point of the frontage. The centre point or central axis is typically, the midpoint and is the highest point of the façade. Both layout and façade form itself demonstrates the predominance of a centrally located heightened space with a dominating central axis in a generally symmetrical form. Its generic shape exhibit a clear hierarchy of massing and spaces. This form mainly consists of a dominant centre axially divided in a symmetrical arrangement. The middle portion is typically elongated into either an enclosed or semi-opened pavilion, which functionally, facilitates the duties of the monarch or administration members to view or hold public events and to gather (Figure 3 and 4). While the back portion is either a 'bumbung panjang' or 'bumbung limas', at times there are variants such as the Minangkabau variant or Kalimantan variant. The simplest generic type may refer to the all timber structure, Istana Malige, Sulawesi and a hybrid variant, the 'Istana Langkat' is a compact axial form, extended porticoes and is surmounted by a multiple layered pitch roof.

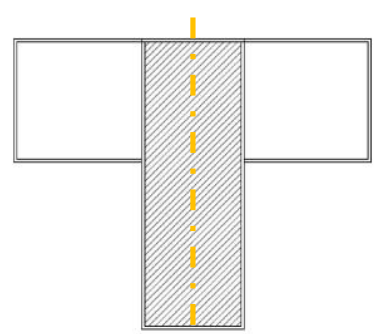

Figure 3: Typical plan of 'Axial Form'

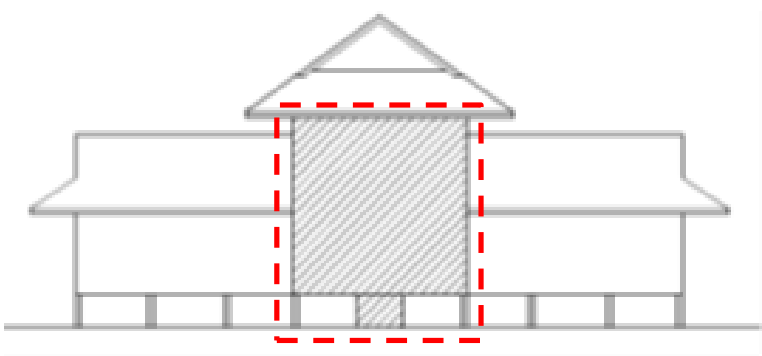

Figure 4: Typical elevation of 'Axial Form'

Further variants are hybrid palaces consisting of timber and masonry structures with a rich treatment such as the Rumah Panglima Ghani (Figure 5). Other variants from the near region is the include Istana Lima Liras, Batu Bara and Istana Langkat, both in Sumatera. All recall the multispaces and extensions of the extinct Melaka Palace, which consists of a series of 'anjung' or 'closed' porticos at the left and right of an imposing dominant central entrance and 
Tengku Anis Qarihah Raja Abdul Kadir, Puteri Shireen J.K, Noor Hanita A.M, \& Zumahiran K.

Classifications of Classical Malay Aristocratic Architecture: Identifying Generic and Variant Forms

protruding balcony or covered balcony. Smaller versions are the Bytun Anwar of Perak (Figure 6, 7 and 8) and the Istana Nyaring, Pattani. At the end of the scale of colonial hybrid is Istana Bandar, of Kelang or Jugra (Table 1).

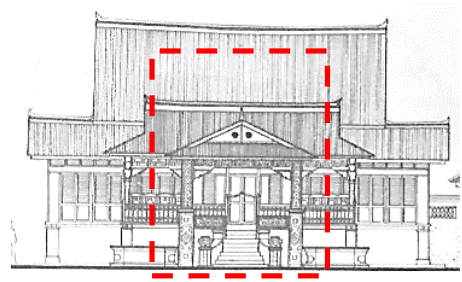

Figure 5: Rumah Penghulu Ghani, Melaka

Sources: KALAM UTM *Dotted lines by author

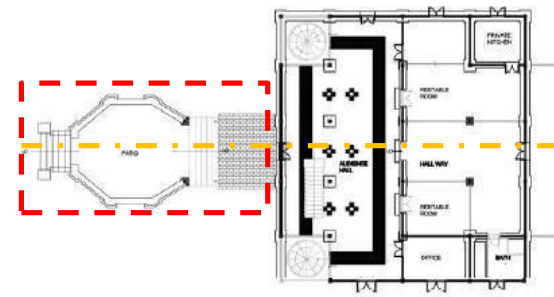

Figure 7: Central entrance with equal elements at left and right of the building Sources: Heritage KAED, IIUM *Dotted lines by author

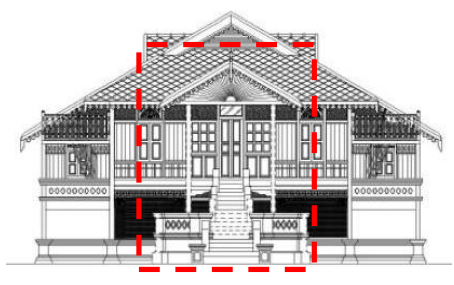

Figure 6: Bytun Anwar, Perak Sources: Heritage KAED, IIUM

*Dotted lines by author

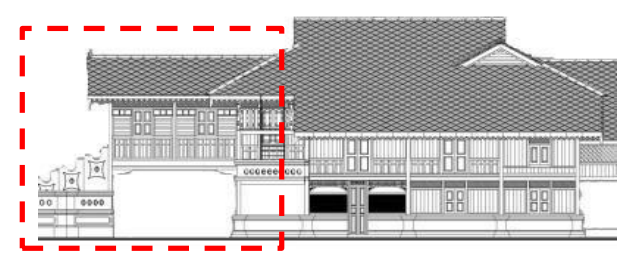

Figure 8: Bytun Anwar - Axial form with protruding structure at the centre Sources: Heritage KAED, IIUM *Dotted lines by author

\section{The 'Binuclear' Form}

As defined by Clark and Pause (2012), binuclear form is a configuration pattern with two equally dominant parts. In this morphological studies, the binuclear saw as a massing where the overall form is essentially capped by two dominated roof and these mirror images of one another. Baitul Rahmah front façade shows that the dominant part of the façade is both protruding elements at the right and left the side of the building which is the 'anjung'. The focus of the façade is the balance and extended structure of the building (Figure 9 and 10). 


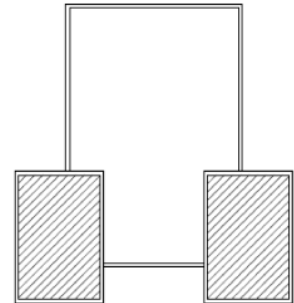

Figure 9: Plan of Binuclear Form

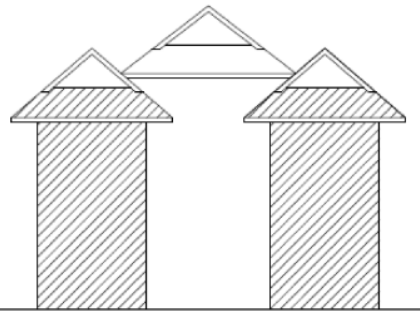

Figure 10: Front façade of Binuclear Form

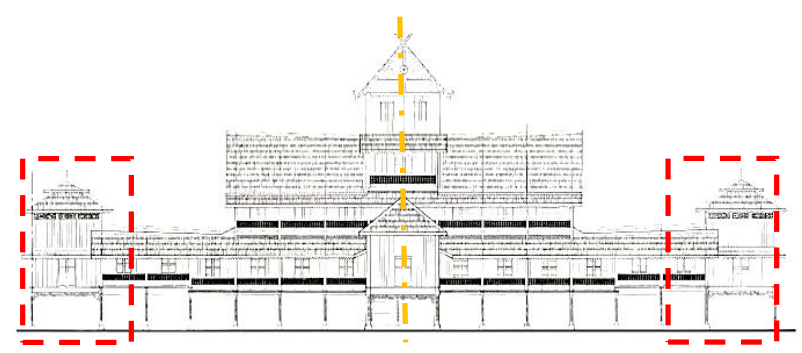

Figure 11: Istana Seri Menanti, Negeri Sembilan Sources: KALAM UTM *Dotted lines by author

The Istana Damnah can be argued as an example of a 'binuclear' 'dual' form where the masonry staircases on left and right divide the main form into two equal parts. Istana Seri Menanti is another variant, yet it can also be argued as a hybrid axial-dual on a scale of forms between generic types (Figure 11 and Table 1). Other examples are Baitul Rahmah of Perak (Figure 12 and 13), Istana Lima Laras of Batu Bara Sumatera (Figure 14), Istana Darul Aman of Langkat, Istana Leban Tunggal of Pahang and Istana Hulu of Perak (Figure 15).

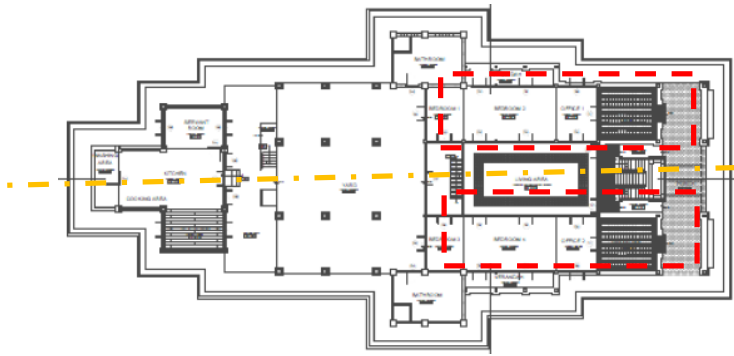

Figure 12: Baitul Rahmah, Perak - plan shows the two protruding elements at both at right and left sides of the building. Sources: Heritage KAED, IIUM *Dotted lines by author

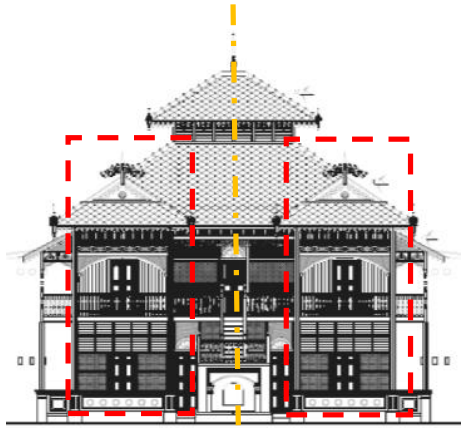

Figure 13: Front façade of Baitul Rahmah, Perak Sources: Heritage KAED, IIUM *Dotted lines by author 
Tengku Anis Qarihah Raja Abdul Kadir, Puteri Shireen J.K, Noor Hanita A.M, \& Zumahiran K. Classifications of Classical Malay Aristocratic Architecture: Identifying Generic and Variant Forms

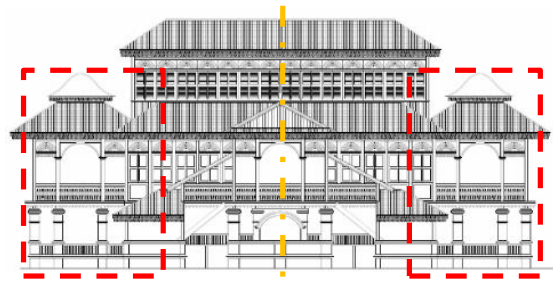

Figure 14: Istana Lima Laras, Batu Bara, Sumatera

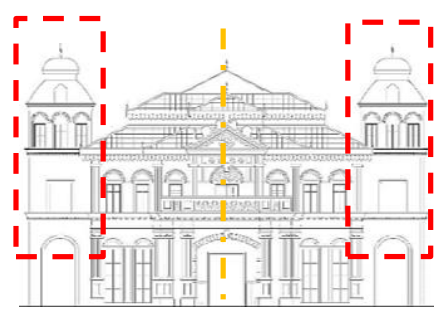

Figure 15: Front façade of Istana Hulu, Perak

Sources: Heritage KAED, IIUM *Dotted lines by author

\section{The Peristyle Form}

Peristyle can defined as a central core shape surrounded by a series of collonaded walkways or spaces. The peristyle form can be argued as a derivation of the axial form, but with a row of columns surrounding space within a building such as a courtyard or internal garden or edging a veranda or porch (Figure 16 and 17).

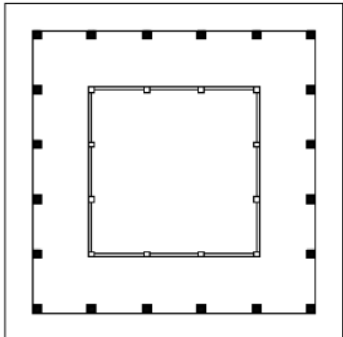

Figure 16: Plan of Peristyle Form

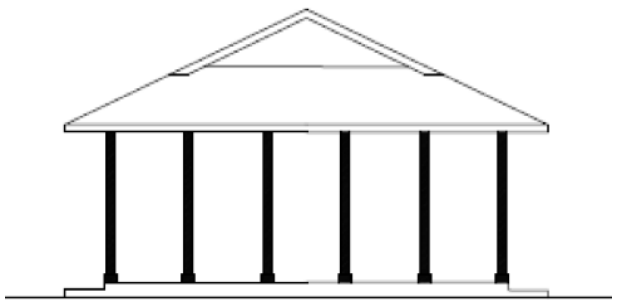

Figure 17: Front façade of Peristyle Form

Renowned examples are the Masjid Kampung Laut of Kelantan, whereby a row of columns surrounds the main prayer hall (Figure 18). Closely spaced columns surrounding the 'Balai Rong' of the Istana Balai Besar, Kedah is one of an outstanding examples of the peristyle form (Figure 19 and 20). Other examples are Istana Pelalawan, Riau and Istana Lama Johor (presently known as Museum Abu Bakar, Johor Bahru).

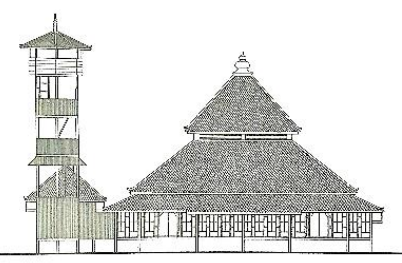

Figure 18: The Front façade of Masjid Kampung Laut Kelantan Sources: KALAM, UTM *Dotted lines by author

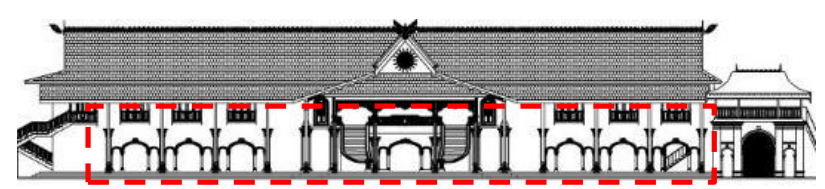

Figure 19: The Peristyle form of Istana Balai Besar, Kedah Sources: Heritage KAED, IIUM *Dotted lines by author 
PLANNING MALAYSIA

Journal of the Malaysia Institute of Planners (2018)

\section{The 'Perabung' Form}

The 'Perabung Lima' form is distinguished by the unique style of the roof, which resembles a five-sided pyramid (the word 'Lima' means five in Malay) influenced by Dutch-style home architecture to shelter 'anjung' or porticos in Malay building.

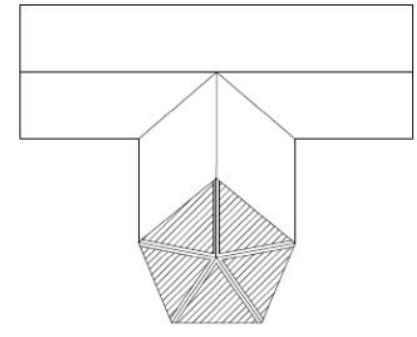

Figure 21: Plan of 'Perabung' Form

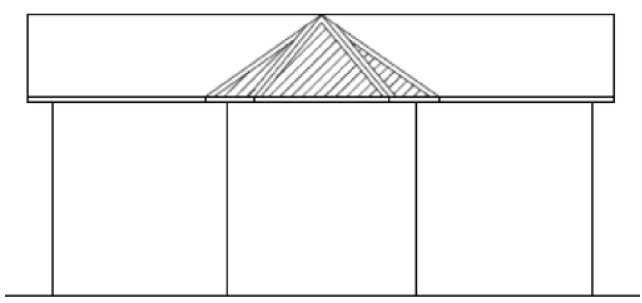

Figure 22: Front façade of Perabung Form

The shape of plans was reflected as 'Perabung Roof Form' and in some cases, it does not look likes pyramidal form but more likely dome shape with segmented planes for example Istana Leban Tunggal, Pahang. As long as the forms have segmented planes, pointed up and looks like a pyramid, dome or cone, the building forms can be categorized under 'Perabung Form'. This Malay form or style was usually found in the states of Kelantan, Perak and Terengganu. It was a favoured style by royal families of their palaces (Figure 21 and 22).

The Istana Kenangan in Kuala Kangsar has the same character of the protruding structure with 'Perabung Lima Roof' on top (Figure 25). It was built as an official residence for the Perak royal family. Istana Jahar, differ to Istana Kenangan whereas the ground floor of the protruding area is only columns without no walls (Figure 23 and 24). The palace has a pentagon-shaped portecochere with the first-floor balcony from which members of the royal family could watch ceremonies held in front of the palace. 
Tengku Anis Qarihah Raja Abdul Kadir, Puteri Shireen J.K, Noor Hanita A.M, \& Zumahiran K.

Classifications of Classical Malay Aristocratic Architecture: Identifying Generic and Variant Forms

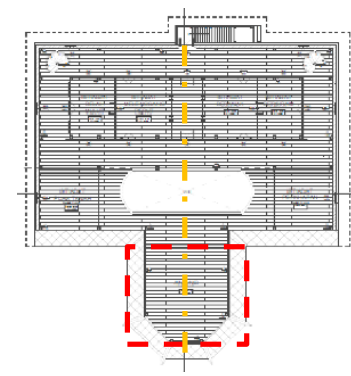

Figure 23: Plan of Istana Jahar, Kelantan Sources: Heritage KAED, IIUM *Dotted lines by author

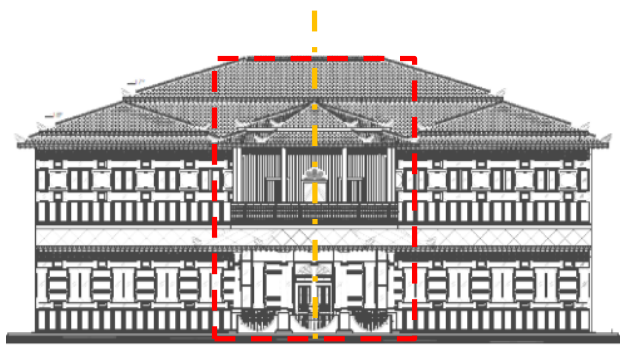

Figure 24: Front Façade of Istana Jahar, Kelantan Sources: Heritage KAED, IIUM *Dotted lines by author

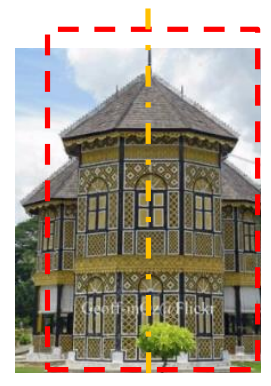

Figure 25: Front

façade of Istana

Kenangan, Perak

\section{The 'Asymmetrical' Form}

The 'Asymmetrical' form refers to a commonly known form in local architecture often seen in Perak and Kedah, whereby the entrance or 'verandah' space distinctively occupies one side of the building (Figure 26 and 27).

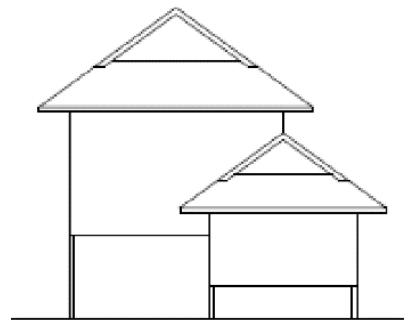

Figure 26: Façade of Asymmetrical Form

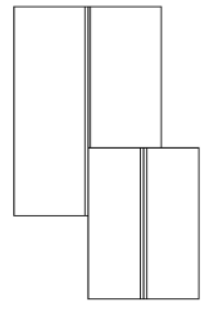

Figure 27: Plan of Asymmetrical Form

The same form is reflected multiple times across Malaysia. The asymmetric form refers to a generic vernacular form, typically seen in typical traditional Malay houses such as the Kutai house, in which the 'verandah' space is deep and is inserted to one side of the Malay house, over a staircase. This 
palatial form is also a characteristic of the vernacular. In this case, the form is a kind of 'regional' Classicality and in seen in the larger scale of palaces such as the asymmetric form of the iconic Istana Tengku Long Terengganu which has a deep, elongated 'verandah' or serambi inserted into one side of the palace form (Figure 28). Other examples are the Villa Tengku Kudin, Penang and Dato's Biji Sura House, Terengganu (Figure 29).

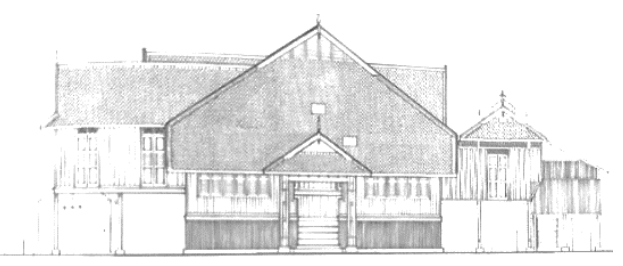

Figure 28: Istana Tengku Long, Terengganu Sources: KALAM, UTM *Dotted lines by author

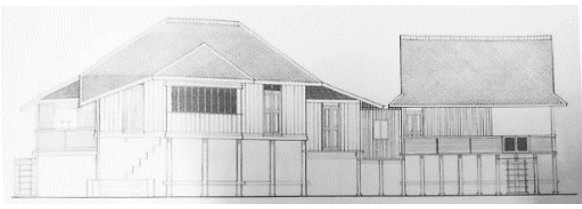

Figure 29: Dato'Biji Sura house, Terengganu House Sources: KALAM, UTM *Dotted lines by author

\section{SUMMARY}

In summary, the general typologies or architypes observed in the public domain of Malay architecture can be categorized into a series of elevation styles and building forms. Such elevation characteristics remain until today, yet there is a need to continuously classify and define them. These archetypes contain some of the best representation of place, and locale and can be used as templates of public complexes. Together with the delicacy of their treatments, the frontages are physical expressions of the 'higher' forms of cultural and aesthetic taste of the Malay society and a reflection of how local architecture and technology had blended and developed over the time. From the analysis of the case studies, these types are described as 'classical' Malay forms which can be formulated into five categories of forms as in Table 1, in evolution and language then be classified further into the 'variants' based on the building's elements and its evolution according to the technology and materials of the era and the region. Column 1 shows refer to cases which are constructed wholly in timber, while Column 2 indicates a hybrid with the ground floor or base of the staircase or bottom pillar being made of brick or masonry. The percentage of timber as a building material of component decreases from column 1 to column 5, shows the pressure of modernisation and how the barometer of modernity in reflected in the materials. What is Malay is still categorised within the evolution as the changes did not drastically affect the Malay Forms as a whole because the forms and styles remain the same even though the expressions had been transmuted from timber to masonry. Table 1 only included 25 case studies of aristocrat's buildings from the Malay World regions (Malaysia and East Sumatra) from the year 1600 - 1920, 
Tengku Anis Qarihah Raja Abdul Kadir, Puteri Shireen J.K, Noor Hanita A.M, \& Zumahiran K.

Classifications of Classical Malay Aristocratic Architecture: Identifying Generic and Variant Forms

which had encapsulated the 5 Malay architecture forms. The building frontages are representative of the era, yet they reflect the breadth of the configurative patterns of the Malay world, and potentially represent models and themes that can be used to design large scale public buildings which should not merely copy imported styles since Malay architecture has its own identity and style.

Table 1: Matrix of Malay architecture palaces - forms and its materials

\begin{tabular}{|c|c|c|c|c|c|}
\hline$\square_{\text {Timber }}$ & & $\Delta$ & & & \\
\hline$\square$ Brick & & $\infty$ & & & \\
\hline & 1 & 2 & 3 & 4 & 5 \\
\hline $\begin{array}{l}\text { Axial } \\
\text { Form }\end{array}$ & Istana Melaka & $\begin{array}{c}\text { Panglima Ghani } \\
\text { House, Melaka }\end{array}$ & $\begin{array}{l}\text { Bytul } \\
\text { Anwar, } \\
\text { Perak }\end{array}$ & $\begin{array}{c}\text { Dato Biji } \\
\text { Sura House } \\
\text { Terengganu }\end{array}$ & $\begin{array}{c}\text { Istana } \\
\text { Bandar, } \\
\text { Selangor }\end{array}$ \\
\hline $\begin{array}{l}\text { Binuclear } \\
\text { Form }\end{array}$ & $\begin{array}{c}\text { Istana Seri } \\
\text { Menanti, N } \\
\text { Sembilan }\end{array}$ & $\begin{array}{c}\text { Istana Lima } \\
\text { Laras, Batu Bara }\end{array}$ & $\begin{array}{c}\text { Baitul } \\
\text { Rahmah, } \\
\text { Perak }\end{array}$ & $\begin{array}{c}\text { Istana Darul } \\
\text { Aman, } \\
\text { Langkat }\end{array}$ & $\begin{array}{l}\text { Istana } \\
\text { Hulu, } \\
\text { Perak }\end{array}$ \\
\hline $\begin{array}{l}\text { Perabung } \\
\text { Lima }\end{array}$ & $\begin{array}{c}\text { Istana } \\
\text { Kenangan, } \\
\text { Perak }\end{array}$ & $\begin{array}{c}\text { Istana Leban } \\
\text { Tunggal, Pahang }\end{array}$ & $\begin{array}{c}\text { Istana } \\
\text { Jahar, } \\
\text { Kelantan }\end{array}$ & $\begin{array}{l}\text { Istana } \\
\text { Bilah, } \\
\text { Perak }\end{array}$ & $\begin{array}{c}\text { Istana } \\
\text { Ternate, } \\
\text { Maluku }\end{array}$ \\
\hline $\begin{array}{l}\text { Peristyle } \\
\text { Form }\end{array}$ & $\begin{array}{c}\text { Masjid Kg. } \\
\text { Laut, Kelantan }\end{array}$ & $\begin{array}{c}\text { Istana Inderagiri, } \\
\text { Renggas }\end{array}$ & $\begin{array}{c}\text { Istana } \\
\text { Damnah, } \\
\text { Riau }\end{array}$ & $\begin{array}{c}\text { Istana Balai } \\
\text { Besar, } \\
\text { Kedah }\end{array}$ & $\begin{array}{c}\text { Istana } \\
\text { Sultan Abu } \\
\text { Bakar, } \\
\text { Johor }\end{array}$ \\
\hline $\begin{array}{l}\text { Asymme } \\
\text {-trical }\end{array}$ & $\begin{array}{l}\text { Istana Tg. } \\
\text { Long, } \\
\text { Terengganu }\end{array}$ & $\begin{array}{c}\text { Kutai House, } \\
\text { Perak }\end{array}$ & $\begin{array}{c}\text { Aristocrat } \\
\text { House, } \\
\text { Penang }\end{array}$ & $\begin{array}{c}\text { Aristocrat } \\
\text { House, } \\
\text { Kelantan }\end{array}$ & $\begin{array}{c}\text { Villa } \\
\text { Tengku } \\
\text { Kudin, } \\
\text { Penang }\end{array}$ \\
\hline
\end{tabular}

The case studies also suggest organising principles for the regional expression as the generic principles of classical Malay language and the essences of traditional form can be defined, into thematic categories without parochial references and later be seen as universal templates and transmuted into modern buildings and urban cities. What is also observed is there is a prevailing common yet intuitive system of proportion and these can be further studied as the basis of building form and elevational design that represent the region. The features and key patterns highlighted here are mainly founded upon the façade and the structure, which has different centres and axis as focal points which are then organised in different ways to create a balanced hierarchy of the façade systems, whether based on symmetry or asymmetry, or repetition. These frontages also reveal the potential of a locally formed expression of 'classical' orders arranged in a certain hierarchy which are found to vary, yet which can later be typified into themes, types and rules. The result suggests even that a probability of ordering such universal styles into the five orders of a regionally-based Classical design, which exists recall an underlying 'five' orders of Malay architecture which should 
PLANNING MALAYSIA

Journal of the Malaysia Institute of Planners (2018)

be further detailed as generic rules or combinations of the principles and grammar of Malay Architecture for public buildings. These can be used to evoke and transmute Malay Architectural identity in the increasing urbanisation of the region's cities and be reflected into the complexity of buildings for the modern world and its urbanised functions.

\section{CONCLUSION}

The significance of advocating a Classical Malay language for the public realm is urgent. This is related to the rising urbanisation of cities in the region and in some nations, the experience of Colonisation has created a rupture between past and present, and produced a vacuum. Without the search for an alternative body of theory, this vacuum will be filled with merely copying the styles and faces of Modernism or other foreign styles not rooted in the region. This research addresses a critical juncture faced by urbanists and policy makers, yet represents only a single part of a larger study. While regional identity holds an emotive link to the locals, the challenge is to rationally analyse what is typically perceived as 'emotive', nostalgic and romanticist. The need to organise principles and vocabulary and hence resources, reveals the capability of transmuting the character of Malay Architecture from the ancient past to the future. This research serves as a starting point to move past the intuitive and emotive into a set of grammar and language, which is crucial is resisting homogeneity and globalisation and instilling identity into cities via modern masonry multi-storey structures. As urbanisation continues its course, the tectonic timber-based vernacular traditions of the region, which are rich and deep in promise, must be studied to derive rules and templates to disseminate, adapt, adopt and transmute such elements and forms into a regional expression within the rising urban and homogenous character of the region. It is also part of the new movement of sustainable modern architecture from which local styles must arise. The goal of ultimately arresting the rapid destruction of local identities in cities amidst globalisation through a universal method of expressing their localities by a forging of a path to bring the past into the 'modern'.

\section{ACKNOWLEDGEMENT}

The authors would like to acknowledge the Transdisciplinary Research Fund (TRGS16-03-001-0001- Characterization of Rules of Malay Architectural Language) from Ministry of Higher Education for the support of this research.

\section{REFERENCES}

Abd Rashid, M. S., \& Che Amat, S. (2009, July). The traditional Malay architecture: Between aesthetics and symbolism. Seminar on Intellectual Property and Heritage Issues in the Built Environment. July 20-21, 2009, Kuala Lumpur, Malaysia.

Amoroso, D. J. (2014). Traditionalism and the ascendancy of the Malay ruling class in 
Tengku Anis Qarihah Raja Abdul Kadir, Puteri Shireen J.K, Noor Hanita A.M, \& Zumahiran K.

Classifications of Classical Malay Aristocratic Architecture: Identifying Generic and Variant Forms

Malaya. Singapore: Singapore University Press.

Andaya, L. Y. (2010). Leaves of the same tree - Trade and ethnicity in the Straits of Malacca. Singapore: NUS Press.

Clark, R. H., \& Pause, M. (2012). Precedents in architecture: Analytic diagrams, formative ideas, and partis. Hoboken, NJ: John Wiley \& Sons.

Evers, B., Biermann, V., \& Thoenes, C. (2003). Architectural theory: from the Renaissance to the present. Köln: Taschen.

Fletcher, B. (1996). Sir Banister Fletcher's a History of Architecture. New York: Architectural Press.

Gullick, J. M. (1987). Malay society in the late nineteenth century: The beginnings of change. Singapore: Oxford University Press.

Hourigan, N. (2015). Confronting classifications - when and what is vernacular architecture? Civil Engineering and Architecture, 3(1), 22-30.

Ibrahim, M. (2017). The genius of tradition: Palatial classicism in the Malay world. In S. Jahn Kassim, N, Nawawi, \& N. Abdul Majid (Eds.), The resilience of tradition, Malay allusions in contemporary architecture. Penang, Malaysia: Areca Publishers.

Jahn Kassim, S., Nawawi, N., \& Abdul Majid, N. (2017). The resilience of tradition, Malay allusions in contemporary architecture. Penang, Malaysia: Areca Publishers.

Measured drawings and Heritage Studies. Kulliyah of Architecture and Environmental Design (KAED) IIUM.

Measured drawings. KALAM, Universiti Teknologi Malaysia (UTM).

Milner, A. C. (2011). The Malays. Chichester: Wiley-Blackwell.

Mohamad Rasdi, M. T., Mohd. Ali, K., Syed Ariffin, S. A. I., Mursib, G., \& Mohamad, R. (2005). The architectural heritage of the Malay World the traditional houses. Skudai, Johor: Penerbit UTM.

Nasir, A. H., \& Wan Teh, W. H. (1997). Warisan senibina Melayu. Bangi: Universiti Kebangsaan Malaysia.

Porphyrios, D. (1982). Classicism is not a style (Volume 52). Michigan: Architectural Design.

Rae, M. (2017). Architecture and theology: The art of place. Waco, Texas: Baylor University Press.

Reid, A. (2004). Understanding Melayu (Malay) as a Source of Diverse Modern Identities. In Journal of Southeast Asian Studies, 32(3), 295-313.

Shuaib, A. A., \& Enoch, O. F. (2013). Application of Kelantan traditional aesthetic values into the architecture of contemporary homes. Arts and Design Studies, 6(15), 1525.

Summerson, J. (1980). The classical language of architecture. London: Thames and Hudson.

Watkin, D. (2011). A history of Western architecture. London: Laurence King Publishing.

Wong, W. (1995). Timber structures in Malaysian architecture and buildings (Master thesis). University of Tasmania, Australia. 